\title{
Fenoldopam Mesylate
}

National Cancer Institute

\section{Source}

National Cancer Institute. Fenoldopam Mesylate. NCI Thesaurus. Code C47531.

The mesylate salt form of fenoldopam, a benzazepine derivative with rapid-acting vasodilator activity. Fenoldopam mesylate is a racemic mixture of S- and R- isomers; the latter is responsible for the biological activity and has a significantly higher affinity for dopamine D1-like receptors (D1 and D5) as well as moderate affinity to alpha-2 adrenergic receptors. This agent selectively activates the dopamine D1-like receptor, thereby causing vasodilatation and increasing renal perfusion. 